\title{
Importance And Behavior Of Capital Project Benefits Factors In Practice: Early Evidence
}

Philip A. Horvath, (E-mail: hap@bradley.edu), Bradley University Patty Hatfield, (E-mail: patty@bradley.edu), Bradley University Donna Hill, (E-mail: donna@bradley.edu), Bradley University

\begin{abstract}
We extend the capital budgeting literature by identifying capital project benefits factors and relating each factor's importance to firm and individual decision-maker factors. We find significant and consistent changes in importance of project benefits factors associated with decision-maker firmindividual factors. Project benefits such as value, scale, profitability, strategic fit, competitiveness, communications and implimentability importance can be explained by decision-makers' firm size or type, line/staff distinctions, power, experience, and behavioral training.
\end{abstract}

\section{Introduction}

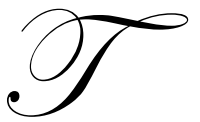

he capital budgeting literature is replete with studies of quantitative capital budgeting procedures in practice. Some of these practices are found to be consistent with normative theory and many are not (cf., Cooper \& Petry (1994), Gitman \& Forrester (1977), Haka, Gordon \& Pinches (1985), Kim (1982), Klammer (1978), Klammer, Koch \& Wilmer (1991), Klammer \& Walker (1984), Pike (1984), Schall, Sundem \& Geijsbeek (1978)). Goitein, Hatfield, Horvath and Webster (1996) have suggested a separate but related stream of research focusing on the qualitative aspects of the capital budgeting process. Hatfield, Hill and Horvath (1999) found empirical support for the idea that industrial buying behavior models, provided in the marketing literature, could explain apparent capital budgeting practice-theory anomalies. They suggest that this model may provide insight that will further converge practice with normative theory. This paper provides added support for the notion that capital budgeting practices can be explained by the stage-gate industrial buying model. We provide firm/individual factors that explain project benefits factor importance rankings of managers acting as gatekeepers at various stages in a stage-gate process. Knowledge of these relationships may enable those responsible for guiding projects through a stage-gate process to package their project more appropriately at different stages of the capital budgeting process.

In this study, both qualitative and quantitative project benefit measures are examined. Specifically, we identified seven project benefits: (1) the impact of the project on firm value, (2) its scale effects, (3) its impact on profitability, (4) its strategic fit, (5) its contribution to firm competitiveness, (6) the project's impact on communications within the firm and (7) the project's implementability. We then examined the interface between characteristics of the firm or individual involved in the capital budgeting process with these seven project benefits. Our findings suggest that both firm size and firm type jointly influence the perceived importance of these different project benefits. Additionally, we find that the power of the gatekeeper affects his/her perception of the importance of various project benefits. We also find other factors that are specific to the gatekeeper influence the importance assigned to various project benefits. These other factors include whether the gatekeeper occupies a line or a staff position, has extensive experience with capital projects, or has a behavioralist background

Readers with comments or questions are encouraged to contact the authors via email. 


\section{Background}

A summary of the history of literature exploring the nature of the relationship between capital budgeting theory and practice is provided in Hatfield, Hill \& Horvath (HHH)(1999). They provide excellent support for the need for studies incorporating the overlap of qualitative and quantitative factors in capital budgeting. Furthermore, HHH found that there are changes in importance of qualitative and quantitative measures as the project proceeds from initial to final approval. Project risk, accounting measure, project fit, cost of capital, present value, earnings based returns, politics, free cash flow measures, and operating cost measures were explained by respondent functional area. Changes in importance and perceived complexity of these factors depend upon the functional area of the individual involved in the preparation and approval of projects. The importance of these factors as well as their perceived complexity is related to the position of the individual involved in the project. HHH also suggest that experience in capital budgeting is not nearly so powerful, by itself, in explaining differences in factor importance or perceived complexity. Clearly, if a project is to complete the capital budgeting approval process the qualitative and quantitative elements provide the information basis for assessment and must be packaged to accommodate each function or position in turn. HHH also find support for three conjectures in their exploration of the stage-gate process (cf., their pages 39-41 for a description of the stage-gate process). These conjectures are: i) the importance of quantitative/qualitative indicators change as a project proceeds through subsequent gates; ii) the complexity of quantitative/qualitative indicators changes in importance as a project proceeds through subsequent gates; and iii) the projects are packaged in order to be sold at each subsequent gate. This paper provides further support for these conjectures.

\section{Motivation}

Whereas the HHH study provided results based on forced answers to a survey with many specific questions we selected an alternative route to obtain bases for analysis. We elected to personally administer a series of open-ended short response questions to upper level managers who had responsibility in the capital budgeting approval process. While the sample size would be reduced, we felt additional insight and/or support of a different type would be obtained through open-ended responses. The questions were designed to allow open-ended responses to key issues surrounding the three conjectures addressed in the HHH study.

The respondents were asked to supply information concerning their occupation, such as place of employment, job title and whether they occupied a line or staff position. Respondents were also asked to specify the functional area in which their undergraduate/graduate degree was received or in which they were trained. Each individual's experience in capital budgeting projects was captured by requesting the number of capital budgeting projects that they had participated in or had approval responsibility. Each respondent was asked rank order, from most important to least important, the major factors or characteristics of capital budgeting projects that are necessary for their approval.

This information would provide a basis for investigating whether respondent's position (rank in the organization), functional area, line/staff responsibility, and/ or degree field, company size and company type would differentiate the factors that respondents felt were more or less important in the assessment of the desirability of capital budgeting projects. If the rank order of a qualitative or quantitative characteristic reliably changes with any of respondent's characteristics then this would support the HHH third conjecture that the projects are packaged in order to be sold at each subsequent gate.

\section{Sample}

A series of focus groups were conducted for a separate purpose. These focus groups were concerned with the capital budgeting processes in place in those firms. Since the topic discussed during the two-hour session was capital budgeting processes in their respective firms the participants in the focus groups were quite oriented to the issues involved in their processes. We devised a set of written questions that were easily and quickly answered and administered to them at the end of each group's discussions. The facilitators of the focus groups consented to append the questions to their sessions. 
The respondents represented six firms. Three of these firms were heavy manufacturing firms with production and administrative facilities around the globe. Two firms were light manufacturing company with international sales and distribution and one other firm was a regional credit union. All firms had headquarters and/or a major presence in the Midwest.

All participants, a total of 46 individuals, in the focus groups were middle to upper level management with major responsibility/ "sign-off" authority on capital projects. Various levels or positions in each company were represented in that firm's group of respondents. Additionally, the respondents represented a wide variety of line and staff functions.

\section{Method}

Responses were coded as follows. Responses of respondents employed by a specific firm were assigned a corresponding value. Firms were ranked on the basis of sales and assets employed on a corporate consolidated basis. The largest firm was ranked as a six and the smallest firm ranked as a one. There were no conflicts in that the firm with the largest sales value also reflected largest total assets and so on through each of the six firms. Company type was coded: a value of three for heavy manufacturing firms, a value of two for light manufacturing and a value of one for the nonmanufacturing company. Within each firm respondent positions were ranked from highest rank, a coded value of ten to the lowest value coded as a one. No effort was made to normalize the position rankings. A zero-one dummy was created to represent line, 0 , or staff, 1 , position of the respondent.

Respondents were asked to provide their undergraduate major or their primary area of training. Respondents who had a MBA were also asked to so indicate. A zero-one dummy was created for each degree/training area with ones being assigned for respondents indicating: Accounting, Business, Economics, Marketing, Engineering, Psychology, or Education as undergraduate majors or primary training areas. Respondents indicating a MBA and who provided an undergraduate area were coded ones in both variables and those respondents who did not indicate an undergraduate major or primary training area were assigned a zero. Responses also provided the number of years of employment with their firm.

Respondents were asked to provide in order of importance those capital budgeting characteristics which they considered in their assessment of the desirability of capital projects. There was no limit to the number of characteristics a respondent could supply and a list was not provided from which the respondent was constrained to choose. Each characteristic was recorded and assigned a rank of one if that respondent listed it as most important, a rank of two if it was second in importance to that respondent and so on.

Factor analysis was then applied to the rankings of the 19 project benefits supplied by the respondents. This data reduction technique was conducted for several reasons. In no case did all of the respondents provide the same set of project benefits. The most frequently ranked benefit was mentioned by only $51 \%$ of the respondents (See Table 1 discussed below). One project benefit was given and ranked by only one respondent. This reduces the appropriate number of observations for each independent variable and impairs the power of regression analysis used below. Factor analysis would combine the project benefits rankings and provide a more suitable set of observations in terms of both sample size and independence of variables for subsequent regression analyses. Finally, factor analysis enables the reduction of the number of regressions to be conducted and thus reduces the probability of obtaining statistically significant results by chance. Results of the factor analysis are presented in Table 2.

There were fourteen different firm/individual variables provided by the respondents. These firm/individual variables were subjected to factor analysis as well. The analysis was conducted for the same reasons as above. The factor analysis should reduce the number of variables representing firm/individual variables. The data reduction technique relieves the pressures on sample size, reduces the likelihood of multicollinearity among the variables, and reduces the number of potential regressions to be conducted to test crucial relationships. Table 3 provides the results of the factor analysis. 
Multiple regression analyses were conducted to determine whether firm/individual factor scores explained the project benefit ranking factor scores provided by respondents. Each project benefits ranking factor was regressed upon all seven of the firm/individual factors. Multiple regression in this form was selected so that any results would have been obtained while controlling for the remaining firm/individual influences and thus produce strong and credible results in spite of the relatively small sample sizes. Using factors obtained above as independent variables also allows for the control of these influences while minimizing multicollinearity issues. Significant regressions and/or significant firm/individual factor coefficients would provide evidence that projects are evaluated differently among managers and that these differences are systematically related to firm and individual characteristics.

\section{Results}

Table 1 provides the 19 different project benefits identified by the 37 respondents in order of decreasing frequency of occurrence in the sample. Also provided in Table 1 are the number and percentage of responses which ranked this characteristic, the minimum ranking value (highest importance), the maximum ranking value (lowest importance), median ranking, mean ranking, and the standard deviation of rankings. No project benefit was mentioned by all of the respondents. Some respondents listed the same project benefit but the ranking was not the same.

\section{Factor Analysis of Ranked Project Benefits}

Factor analysis of the ranked project benefits variables produced seven factors. These factors, their constituent project benefits variables, and rotated factor scores are provided in Table 2. Cash flow, Flexibility, ROI and Timing load together to constitute factor 1. Factor 2 includes Capacity, New Product, Operating Costs, and Payback. Factor 3 is made up of Margin, Quality, Returns and Safety loaded together. Corporate Goals and Sponsor make up factor 4. Factor 5 consists of Buy In, Functional Properties and Project Cost. Factor 6, and factor 7 are comprised of Communications (intra-firm) and Competition respectively.

Cash Flow, Flexibility, ROI, and Timing all refer to the underlying issue of the value of the project. Cash Flow and ROI reflect long-term financial aspects of the project which are inextricably linked to the impact of the project on the firm's value. The Timing and the Flexibility variables are aspects of each project which potentially alter the value of the project. The ability to accelerate or delay implementation of a project may impact the value of a project as might a project's flexibility or amenity to alternative uses. Increases in project benefits factor 1 (Value) through the interactions of values of its components can then be said to reflect increased importance of project value to a particular respondent.

Capacity, New Product, Operating Costs, and Payback are all project benefits variables which address issues concerning firm scale. Project impact on current capacity or planned capacity adjustments are issues that directly address consideration of the project's fit with the firm's current or planned scale of operations. Projects associated with new products may affect or be affected by current or planned firm scale. Operating costs and Payback (a liquidity indicator) are concerned with a project's impact on firm scale. Changes in operating costs alter the ability of the firm to operate at a given scale of funding and changes in payback modify those changes in scale by providing more, or less, self-funding at any given scale of operations. Project benefits factor 2 (Scale) importance values reflect the importance of a project's impact on the scale of the firm's operations.

Project benefits factor 3 (Profitability) was composed of Margin, Quality, Returns, and Safety. These variables are interpretable as indicators of project profit. Margin is reflective of the project's contribution of overhead and profit in a relatively straightforward manner. Returns is likewise a profit derived concept. An increase in a project's margin and/or returns reflects an increase in project profitability. Quality and Safety also reflect project profitability. As a project enhances the quality of the firm's product(s) more units are likely to be sold and fewer flawed units would be produced. Quality and Safety also enhance profitability. In the same manner, Safety directly influences firm profitability. Project benefits factor 3 can then be interpreted as connoting importance of firm profitability.

Project benefits factor 4 (Strategic Fit) best reflects the notion of strategy. Its loading on project benefits variables Corporate Goals and Sponsorship provide little room for interpretation. Project consistency with corporate 
goals is a purely strategic consideration. Project sponsorship similarly reflects consideration of the importance of the sponsor vouching for the project's consistency with the overall strategy of the firm.

Implementability is an obvious connection conveying the meaning of project benefits factor 5 (Project Implementability). Buy in, project Functional Properties, and Project Cost each impact the ease and effectiveness with which the project may be implemented.

The remaining two project benefits factors contain one project benefits variable each. Factor 6 (Communications), is composed solely of communications, indicates relative importance of project impact on communications and would differ by importance ranking to the extent internal communications are deemed important. Likewise factor 7's (Competition) loading on competition reflects perceived importance of the project's contribution to the ability of the firm to meet or react to competition, if not preempt the competition in any given product or market.

Project benefits factors 1 through 7 will be discussed in terms of project impact on firm Value, Scale, Profitability, Strategic Fit, Project Implementability, Communications, and Competitiveness. Throughout the remainder of the paper factor score based variables, identified here and below, will be distinguished by italics. This will identify variables as separate from surrounding text without introducing confounding complexity.

\section{Factor Analysis of Institutional and Individual Variables}

Table 3 provides the seven factors produced by the data reduction of the 14 firm/individual variables with each rotated score. Factor 1 (Firm Size/Type) groups together company size, company type, and the education degree dummy. Factor 2 (Respondent Line/Staff) consists of line-staff dummy, accounting degree dummy and the engineering degree dummy loadings. Factor 3 (Respondent Power) includes loads on respondents position, business degree dummy and respondents' years with the firm. Number of projects the respondent had participated in and the MBA dummy loaded together to form factor 4 (Respondent Experience). Factors 5 (Respondent Marketing), 6(Respondent Rationalist), and 7 (Respondent Behavioral) consists of factor loadings for marketing degree, economics degree, and psychology degree dummies respectively. The original firm/individual variables constituting each factor was based upon the factor exhibiting the highest varimax rotated factor score. All but one of the rotated factor scores were greater than 0.60. The variable that loaded lowest was respondents' reported years of experience with the firm in factor 3 at 0.530 .

Firm/individual variable associations described in Table 3 and noted above for each factor should likewise reflect some underlying intuition if their use is to provide insight into the process. Firm/individual factor 1 consists of firm/individual variables: Company Size, Company Type and the Education Degree Dummy. In our sample, the larger firms also tended to be heavy manufacturing, smaller firms were light manufacturing and the smallest firms were nonmanufacturing. The dominance of these variables coupled with the negative sign of the Education Degree factor loading suggest that firms of similar Size/Type tend to behave similarly.

Loaded on firm/individual factor 2 are the Line-Staff Dummy, Accounting Degree Dummy, and Engineering Degree Dummy. Given the nature of firms this grouping is not at all surprising. This factor is taken to reflect differences in views taken by line personnel as opposed to staff.

Respondent Position, Respondent Years With the Company variables and the Business Degree Dummy comprised firm/individual factor 3 . These variables taken together reflect the relative power of the respondent. Differing rankings may be explained by the power status of the respondent.

Firm/individual factor 4 was made up of the MBA Dummy and the Number of Projects the respondent participated in firm/individual variables. These variables suggest that experience with capital budgeting either in terms of number of projects in which the respondent has participated in and/or formal training via an MBA degree may explain differences in importance rankings given the project benefits.

The Marketing Degree Dummy (representing a marketing background), Economics Degree Dummy 
(representing a rationalist background), and Psychology Degree Dummy (representing a behavioralist background)were the sole firm/individual variables included in firm/individual factors 5, 6, and 7 respectively. These factors, each comprised of a single firm/individual variable, suggest that respondents with or sharing specialties in their undergraduate education may provide additional explanatory power for differing importance rankings assigned to project benefits.

Firm individual factors may then be interpreted in terms of : 1) Firm Size/Type; 2) Respondent Line/Staff ; 3) Respondent Power; 4) Respondent Experience; 5) Respondent Marketing background; 6) Respondent Rationalist background, and finally; 7) Respondent Behavioral background corresponding to firm/individual factors 1 through 7 respectively.

\section{Project Benefits Factors Regressions on Firm and Individual Factors}

Table 4 provides the results of the multiple regressions of each project benefits ranking factor on all of the firm/individual factors. Of the seven regressions conducted four produced equations that were significant. The regression of Value on the seven firm/individual factors was significant at the 0.01 level $(\mathrm{Sig} F=0.000)$ with an $\mathrm{r}^{2}=$ 0.546. Significant at the 0.025 level (Sig $\mathrm{F}=0.024$ ) with $\mathrm{r}^{2}=0.351$ was the regression of Scale on all seven firm/individual factors. Strategic Fit regression on all seven firm/individual factors produced an equation which was significant at the 0.01 level $(\mathrm{Sig} F=0.001)$ with an $\mathrm{r}^{2}=0.465$. The Communications multiple regression on all seven firm/individual factors was significant at the 0.10 level (Sig F $=0.083$ ) with an $\mathrm{r}^{2}=0.286$.

While four of the seven multiple regressions produced significant equations, all seven of the project benefits ranking factors could be said to be related to at least one firm/individual factor at the 0.10 level or better. Not all seven of the firm/individual factors, however, exhibit significant relationships with a project benefits factor. Rationalist and Marketing background show no systematic explanatory power for any of the project benefits factors at the 0.10 level or better.

The Value multiple regression produced a beta of 0.381 , significant at the 0.01 level ( $\mathrm{Sig} \mathrm{t}=0.000$ ), for Firm Size/Type. Respondent Power reflected a beta that was significant at the 0.05 level $(\operatorname{Sig} \mathrm{t}=0.031)$, of -0.142 . A beta of 0.014 was obtained for Experience which was significant at the 0.01 level $(\mathrm{Sig} t=0.001)$. Remaining firm/individual factors exhibited no coefficients that were significant at the 0.01 level or better. The intercept was also found to be not significantly different from zero.

Scale, when regressed on the seven firm/individual factors, generated two significant results. Firm Size/Type had a coefficient of 0.194 which was significant at the 0.025 level $(\mathrm{Sig} t=0.025)$, and Respondent Power was assigned a beta of -0.145 , significant at the 0.10 level $(\mathrm{Sig} t=0.053$ ). The regression constant and the remaining independent variable coefficients were not significantly different from zero.

In the regression of Profitability, only Respondent Power was significant at the 0.10 level of better. A beta of 0.473 was obtained which was significant at the 0.01 level $(\mathrm{Sig} t=0.003)$. While the remaining independent variable coefficients were not found to be significant, the intercept was valued at 2.680 and was found to be significant at the 0.05 level $(\operatorname{Sig~t}=0.013)$.

Strategic Fit regression on the firm/individual factors yielded significant coefficients for Respondent Line/Staff and Respondent Power. Respondent Line/Staff exhibited a coefficient of -0.265 which was significant at the 0.10 level $(\mathrm{Sig} \mathrm{t}=0.076)$ and Respondent Power reflected a beta coefficient of 0.219 which was significant at the 0.01 level $(\mathrm{Sig} \mathrm{t}=$ $0.000)$. While the constant of -0.736 was significant at the 0.05 level $(\operatorname{Sig} t=0.045)$, the remaining firm/individual factor coefficients were not found to be significantly different from zero.

Respondent Line/Staff and Behavioral background were found to be significant at the 0.01 level in explaining Competitiveness. Respondent Line/Staff yielded a beta of $-0.637(\mathrm{Sig} \mathrm{t}=0.076)$ and Behavioral background had a beta of $-3.298(\mathrm{Sig} \mathrm{t}=0.074)$. The remaining firm/individual factors were not found to be significant. However, the constant of 1.961 was found to be significant at the 0.05 level $(\operatorname{Sig~t}=0.045)$. 
When Communications was regressed on firm/individual factors only Respondent Power produced a reliably non-zero beta. Respondent Power provided a coefficient of -0.282 which was significant at the 0.01 level $(\operatorname{Sig} t=0.003$ ). The constant produced in the regression was significant at the 0.10 level $(\mathrm{Sig} t=0.087)$ with a value of 1.066 .

The final regression of Implimentability on the seven firm/individual factors indicated that the intercept was reliably non-zero at the 0.10 level $(\mathrm{Sig} t=0.055)$ and was valued at 0.867 . Behavioral background was the sole independent variable which was found to be significant. Behavioral background was significant at the 0.025 level $(\operatorname{Sig} \mathrm{t}=$ 0.015 ) with a coefficient of 2.342 .

\section{Discussion}

Projects benefits factors interpretations which are explained by firm/individual factor interpretations are summarized in Table 5. Table 5 provides only significant relationships in a more intuitive manner than that found in the more formal Table 4. Since the Marketing background and Rationalist background factors were not significantly related to any of the project benefits factors in the regression results given in Table 4, they were omitted from Table 5. Also included in Table 5 is the direction of change in importance of each project benefits factor with increases in each relevant firm/individual factor.

By far the most pervasive result is that Respondent Power explains changes in importance in all but two of the project benefits factors. The Value, Scale, Profitability, Strategy, and Communications project benefits importance factors are explained by Respondent Power. The greater the power of the respondent the more important project value, project effect on firm scale, project impact on firm profitability, and on intra-firm communications become. While these factors increase in importance as power increases, strategic issues decrease in importance as the respondent's power increases. One would expect that a project evaluator's perceptions of importance of project value, scale, profitability and communications would increase with the power of the individual. That the strategic fit of the project diminishes in importance seems puzzling. One possible explanation may be that as one's power is enhanced, the one's ability to redirect, improve or otherwise modify the strategy of the firm would also increase. It may be that power may reflect an inherent responsibility on the part of the individual to safeguard the firm's value to rank projects more highly which increase firm value, scale, profitability, and/or communications but in new and creative directions.

Respondents in large, manufacturing firms rate project effects on firm value less highly than do those in smaller light manufacturing firms and subsequently less than to those in the small non-manufacturing firms. Similarly firm scale effects of projects are reduced in importance as one moves from large manufacturing to small non-manufacturing companies. The respondents in large manufacturing firms may feel that scale is just not an issue given their size and that any project either will not tax the firm's scale, ability to operate at differing levels, nor will have appreciable effects on scale. This may imply that those evaluating projects in larger manufacturing firms find their fixed assets as given and insensitive to capital project initiation. Scale may be a real issue to the smaller or small firm, given the reduced base of capacity to produce or provide a given product or service. Similarly, project managers may view the firm's value as being established and the effects of any project as negligible, perhaps value maintaining as opposed to value enhancing. Small firms would be in positions in which their overall value could be appreciably modified by a given project.

This significance of the line/staff dummy in explaining strategic fit and competitiveness importance is reminiscent of the old line-staff conflict established in the various myths that are perpetuated among managers in firms of all sizes and types. Staff evaluators rank project strategic fit and competitiveness contributions more highly than line evaluators.

The behavioralist respondents rank competitiveness as more important than the average and rank implimentability as less important than the average respondent. Those trained in the nuances of perception and behavior perceive increases in the firm's ability to compete as more important than those otherwise trained. These same respondent characteristics appear to view project implimentability to less important than those trained in other areas. 
The relative importance of project effect on value is ranked more highly by respondents with more experience than those with less. Those respondents who have greater experience with capital budgeting and participation in capital budgeting projects appear to emphasize the importance of the impact of the project on the value of the firm.

\section{Conclusions}

The results of our simple investigation have identified essentially seven factors that are considered to be important in the selection of capital projects. These factors are viewed as being project benefits. Projects presented for approval through the firm are evaluated variously on the basis of the project's 1) contribution to the value of the firm;2) the project's effects on the scale of the firm; 3 ) the contribution of the project to the firm's profitability; 4) the project's strategic fit; 5) the project's ability to improve or maintain the firm's competitiveness; 6) the project's effects on the communications within the firm, and; 7) the project's implimentability.

The relative importance of these project benefits are explained by 1) the size/type of the firm considering the project; 2) whether the evaluator occupies a line or a staff position; 3 ) the power of the evaluator; 4) the experience of the evaluator, and 5) whether the evaluator is trained as a behavioralist. Not all project benefits importance assessments are explained by all five of these evaluator characteristics.

Aside from the obvious point that different people see things differently we have established a suggestion for a paradigm. If one assumes that projects are packaged and sold in some semblance of a Stage-Gate Process as suggested by Hatfield, Hill and Horvath (1999), our results suggest strategies along which the projects may be packaged as project proposals proceed from one stage to each subsequent stage with evaluators acting as gates.

The project's contribution to the value of the firm is viewed as less important in large, manufacturing firms, viewed as more important by those possessing greater power and with more experience than otherwise. The project's effects on firm scale are evaluated as less important in large manufacturing firms than otherwise and as more important by those with greater power than otherwise. Project effects on firm profitability are seen here to be more important to those with greater power, but not particularly sensitive to other explanatory variables considered here. Strategic fit of projects is seen as more important by those occupying staff positions than by those performing line functions. Strategic fit of projects is seen as less important to more powerful evaluators; perhaps because of their desire to steer or direct the firm's strategy through the asset selection process. Individual evaluators who are members of the firm's staff are tend to rank competitiveness as more important than line managers as are those with behavioral backgrounds. Those with increased power give more weight to project effects on communications than do others. Evaluators with behavioral backgrounds rank a project's implimentability as less important than the average evaluator.

While all project benefits apparently require consideration, project value would be de-emphasized in large manufacturing firms but emphasis on value would be increased for presentation to evaluators at each more powerful stage as would presentations to those with more experience in capital budgeting. Similarly project scale effects may always be an issue, but less so in large manufacturing firms and more so in small non-manufacturing firms. Scale issues would take on increased emphases, along with value issues, as evaluators are imbued with greater power. When projects are presented to gatekeepers with ever more power, project profitability would likewise be given more exposure. If one wishes approval from a gatekeeper occupying a staff position more exposure may be given the project's strategic fit, but if the gatekeeper is in a more powerful position strategic fit may be relatively diminished in exposure. The project's contribution to the firm's competitive position may be given more exposure to those in staff positions and/or those who are trained behavioralists. Those in power may wish to see more consideration of project impacts on communications. While expanded consideration of implementation issues may dissuade a gatekeeper with a behavioralist background. Our findings are consistent with the findings and suggestions of Hatfield, Hill and Horvath (1999).

When packaging the project for sign-off then, different "packages" may be appropriate at different stages of the project approval process. While this initial investigation does not provide all of the answers, we believe that it identifies a number of insights for those individuals involved in the capital budgeting process. Additionally, it explains, to a large extent, why neither quantitative nor qualitative measures alone are sufficient for project approval and implementation. 
We also believe that this study provides a set of conjectures that are suitable for rigorous testing as the quest for understanding the dynamics of the capital budgeting process continues.

\section{References}

1. Anderson, P.E. and T.M. Chambers, “A Reward/Measurement Model of Organizational Buying Behavior,” Journal of Marketing, Vol. 49 (Spring), pp. 7-23, 1985.

2. Bertrand, K. "Survey Finds Many 'Critical' Buying Criteria," Business Marketing, Vol. 72 (April), pp. 30-31, 1986.

3. Bonoma, T. V., "Major Sales: Who Really Does the Buying?" Harvard Business Review, (May-June), pp. 111119, 1982.

4. Cooper, D., and G. Petry, "Corporate Performance and Adherence to Shareholder Wealth-Maximizing Principles," Financial Management, Vol. 23, No. 3 (spring), pp. 71-78, 1994.

5. Cooper, R. G., "Stage-Gate Systems: A New Tool for Managing New Products," Business Horizons, (MayJune), pp. 44-54, 1990.

6. Gitman, L. and J. Forrester, "A Survey of Capital Budgeting Techniques Used by Major U.S. Firms," Financial Management, (fall), pp.66-76, 1977.

$7 . \quad$ _ a a _ a C.E. Maxwell, “A Longitudinal Comparison of Capital Budgeting Techniques Used by Major U.S. Firms: 1986 Versus 1976,” The Journal of Applied Business Research, (fall), pp. 41-50, 1978.

8. Goitien, B., P. Hatfield, P. Horvath and A. Webster, "Financial Criteria, Capital Budgeting Techniques, and Risk Analysis of Manufacturing Firms," The Journal of Applied Business Research, Vol. 13, No. 1 (winter), pp. 95-104, 1996.

9. Haka, S., L. Gordon, and G. Pinches, "Sophisticated Capital Budgeting Techniques and Firm Performance," The Accounting Review, (October), pp. 651-669, 1985.

10. Hatfield, P., D. Hill, and P. Horvath, "Industrial Buying and Divergence of Capital Budgeting Theory and Practice: An Exploration,” Journal of Applied Business Research, Vol. 15, No. 1, (winter), pp. 37-46, 1999.

11. Jackson, B. B., "Build Customer Relationships That Last," Harvard Business Review, (November-December), pp. 120-128, 1985.

12. Kim, S., "An Empirical Study on the Relationship Between Capital Budgeting Practices and Earnings Performance," Engineering Economist, (spring), pp. 185-196, 1982.

13. Klammer, T., "The Association of Capital Budgeting Techniques and Firm Performance," The Accounting Review, (April), pp. 353-464, 1978.

14. __ B. Koch and N. Wilmer, "Capital Budgeting Practices - A Survey of Corporate Use," Journal of Management Accounting Research, (fall), pp. 447-464, 1991.

15. ___ and M. Walker, "The Continuing Increase in the Use of Sophisticated Capital Budgeting Techniques," California Management Review, (fall), pp. 137-148, 1984.

16. Pike, R., "Sophisticated Capital Budgeting Systems and Their Association with Corporate Performance," Managerial and Decision Economics, Vol. 5, No. 2, pp. 91-97, 1983.

17. Schall, L.D., G.L. Sundem and W.R. Geijsbeek, Jr., "Survey and Analysis of Capital Budgeting Methods," Journal of Finance, Vol. 33, No. 1 (March), pp. 281-287, 1978.

18. Sundem, G., "Evaluating Capital Budgeting Models in Simulated Environments," Journal of Finance, Vol. 30 (September), pp. 997-992, 1975. 
Table 1

\section{Descriptive Statistics Of Project Benefits Importance Rankings}

Benefits importance rankings were provided by managers/executives who have experience and involvement in capital project evaluation and who were participants in focus groups. Project Characteristics are defined as: 1) Functional Properties refers to the methods and modes of operation, speed, etc., associated with the project; 2) Capacity refers to the implications of the project on firm scale or scope of production; 3) Quality refers to the classification of the project as affecting product/service quality; 4) Returns refers to the project's impact on firm returns; 5) Safety refers to the classification of the project as affecting or improving employee or product safety; 6) Payback refers to the number of years for the project to earn its cost; 7) Operating Costs refers to the costs of operating the project or the impact of the project on operating costs; 8) ROI refers to the project's return on investment; 9) Corporate Goals refers to the project's consistency or fit with corporate goals; 10) Sponsor refers to the importance of the project's sponsor, if any, on project selection; 11) Project Cost refers to the initial cost of the project or the project's fit within the firm's capital budget; 12) Margin refers to the project's operating margin; 13) Competition refers to the project's competitive effect or whether the project is required because a competitor is or has adopted similar project(s); 14) Make/Buy refers to the classification of the project as a make or buy decision; 15) Timing refers to the deferability of the project; 16) Flexibility refers to the projects ability to be put to multiple uses; 17) Cashflow is the cash generated by the project; 18) Buyin is the predisposition of decision makers toward the project, usually accomplished by the project generating unit; 19) Communications refers to the project's impact on intra-firm information exchange; 20) New Product is the classification of the project as the generation of a new product or service.

\begin{tabular}{lccccccc}
\hline $\begin{array}{c}\text { Project } \\
\text { Characteristic }\end{array}$ & $\begin{array}{c}\text { Nr. Of } \\
\text { Responses }\end{array}$ & $\begin{array}{c}\text { Percent of } \\
\text { Responses }\end{array}$ & $\begin{array}{c}\text { Minimum } \\
\text { Importance } \\
\text { Ranking }\end{array}$ & $\begin{array}{c}\text { Maximum } \\
\text { Importance } \\
\text { Ranking }\end{array}$ & $\begin{array}{c}\text { Median } \\
\text { Importance } \\
\text { Ranking }\end{array}$ & $\begin{array}{c}\text { Mean } \\
\text { Importance } \\
\text { Ranking }\end{array}$ & $\begin{array}{c}\text { Importance } \\
\text { Ranking } \\
\text { Standard } \\
\text { Deviation }\end{array}$ \\
Functional & & & & & & & \\
Properties & 22 & $51.16 \%$ & 1 & 6 & 1 & 2.23 & 1.88 \\
Capacity & 21 & $48.84 \%$ & 1 & 7 & 3 & 2.67 & 1.39 \\
Quality & 15 & $34.88 \%$ & 2 & 6 & 4 & 4.33 & 0.98 \\
Returns & 15 & $34.88 \%$ & 1 & 4 & 2 & 2.20 & 0.68 \\
Safety & 13 & $30.23 \%$ & 1 & 5 & 3 & 3.00 & 1.16 \\
Payback & 13 & $30.23 \%$ & 1 & 9 & 2 & 2.77 & 2.46 \\
Operating Costs & 10 & $23.26 \%$ & 1 & 10 & 4 & 4.10 & 2.42 \\
ROI & 9 & $20.93 \%$ & 1 & 3 & 1 & 1.44 & 0.73 \\
Corporate Goals & 9 & $20.93 \%$ & 1 & 3 & 2 & 1.89 & 0.78 \\
Sponsor & 7 & $16.28 \%$ & 2 & 4 & 3 & 3.00 & 0.82 \\
Project Cost & 7 & $16.28 \%$ & 2 & 5 & 3 & 3.43 & 0.98 \\
Margin & 7 & $16.28 \%$ & 1 & 6 & 4 & 3.57 & 1.72 \\
Competition & 7 & $16.28 \%$ & 1 & 4 & 3 & 2.29 & 1.25 \\
Make/Buy & 6 & $13.95 \%$ & 2 & 7 & 3 & 3.50 & 1.87 \\
Timing & 5 & $11.63 \%$ & 3 & 7 & 5 & 5.20 & 1.48 \\
Flexibility & 5 & $11.63 \%$ & 5 & 8 & 7 & 6.60 & 1.14 \\
Cashflow & 5 & $11.63 \%$ & 1 & 6 & 2 & 2.80 & 1.92 \\
Buyin & 4 & $9.30 \%$ & 1 & 6 & 6.5 & 6.5 \\
Communications & 2 & $4.65 \%$ & 5 & 8 & & 1.00 & 2.50 \\
New Product & 1 & $2.33 \%$ & 1 & 1 & & 2.12 \\
\hline
\end{tabular}


Table 2

Project Benefits Importance Factor And Factor Components With Rotated, Normalized Factor Scores

\begin{tabular}{|c|c|c|}
\hline $\begin{array}{l}\text { Project Benefits Importance } \\
\text { Factor Name }\end{array}$ & $\begin{array}{c}\text { Project Benefits Importance Factor } \\
\text { Components }\end{array}$ & $\begin{array}{l}\text { Project Benefits Importance Component } \\
\text { Rotated, Normalized Factor Scores }\end{array}$ \\
\hline \multirow[t]{4}{*}{ Value } & Cashflow & 0.840 \\
\hline & Flexibility & 0.683 \\
\hline & Roi & 0.942 \\
\hline & Timing & 0.824 \\
\hline \multirow[t]{4}{*}{ Scale } & Capacity & 0.549 \\
\hline & New Product & 0.907 \\
\hline & Operating Costs & 0.690 \\
\hline & Payback & 0.828 \\
\hline \multirow[t]{4}{*}{ Profitability } & Margin & 0.750 \\
\hline & Quality & 0.586 \\
\hline & Returns & -0.707 \\
\hline & Safety & 0.749 \\
\hline \multirow[t]{2}{*}{ Strategic Fit } & Corp Goals & -0.685 \\
\hline & Sponsor & -0.885 \\
\hline \multirow[t]{3}{*}{ Implementability } & Buy In & 0.817 \\
\hline & Functional Properties & 0.614 \\
\hline & Project Cost & -0.465 \\
\hline Communication & Communications & 0.923 \\
\hline Competition & Competition & 0.948 \\
\hline
\end{tabular}

Table 3

Respondent Degrees And Training Factors With Factor Components And Rotated, Normalized Factor Scores

Respondent Degrees/Training Factor Name

Firm Size/Type

Respondent Line/Staff

Respondent Power

Respondent Experience

Marketing

Rationalist

Behavioral

\section{Respondent Degrees/Training} Factor Components

Company Size

Company Type

Education Degree

Line-Staff

Accounting Degree

Engineering Degree

Position

Business Degree

Years With Company

Number Of Projects

$$
\text { MBA }
$$

Marketing Degree

Economics Degree

Psychology Degree
Respondent Degrees/Training Component Rotated Factor Scores

0.821

0.903

$-0.698$

0.743

0.890

$-0.663$

0.815

0.802

0.530

0.648

0.858

0.940

0.952

0.983 


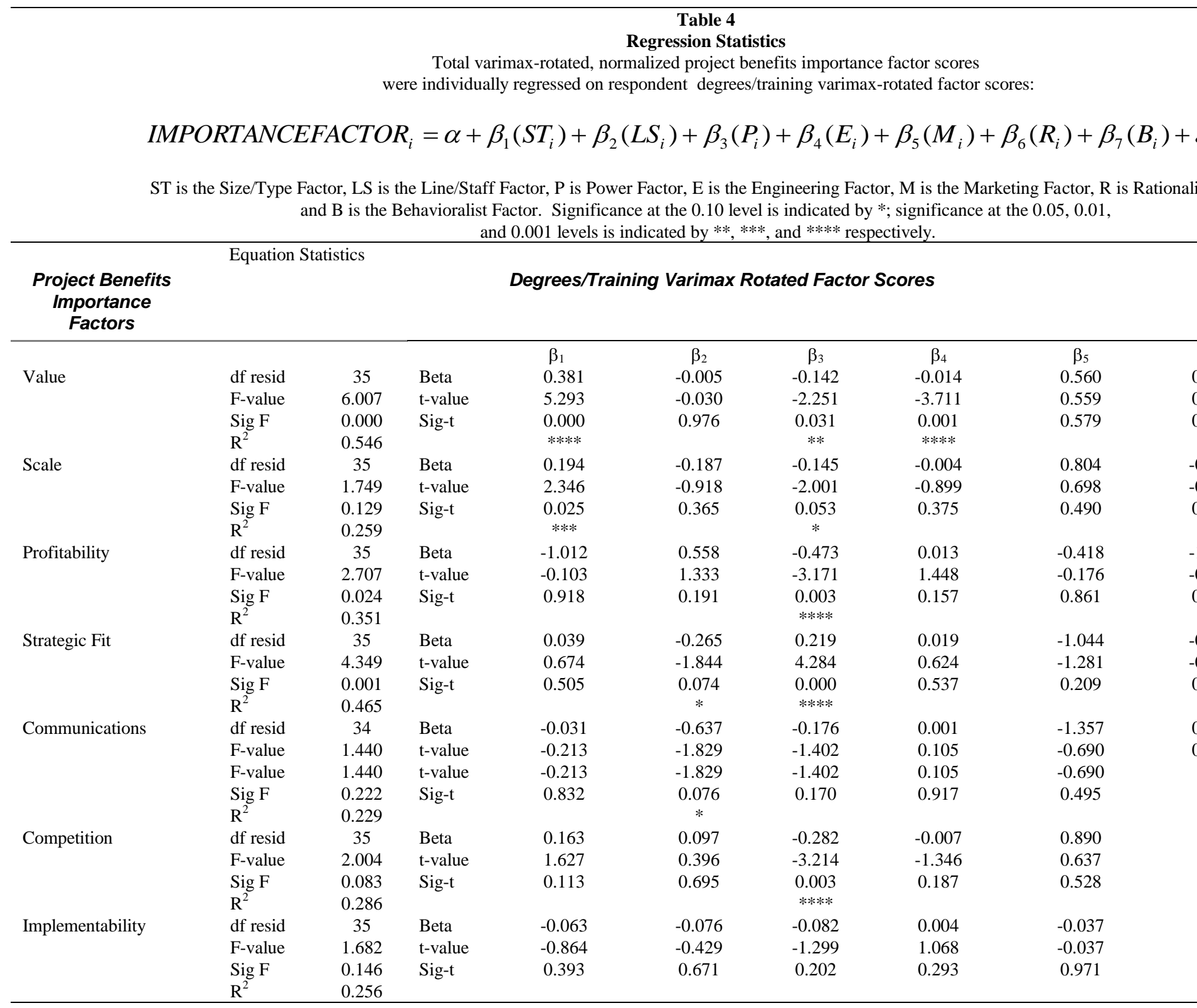

Table 5

Summary Of Significant Factor Relationships

Direction Of Change In Importance Of Project Benefits Importance Factors Given An Increase In Degrees/Training Factors

\begin{tabular}{|c|c|c|c|c|c|}
\hline \multirow{3}{*}{$\begin{array}{l}\text { Project Benefits } \\
\text { Importance Factors }\end{array}$} & \multicolumn{5}{|c|}{ Significant Degree/Training Factors } \\
\hline & Firm & Respondent & Respondent & Respondent & Behavioral \\
\hline & Size/type & Line/Staff & Power & Experience & \\
\hline Value & $\begin{array}{l}\text { Decreased } \\
\text { Importance }\end{array}$ & & $\begin{array}{l}\text { Increased } \\
\text { Importance }\end{array}$ & $\begin{array}{l}\text { Increased } \\
\text { Importance }\end{array}$ & \\
\hline
\end{tabular}




\begin{tabular}{llll}
\hline Scale & $\begin{array}{l}\text { Decreased } \\
\text { Importance }\end{array}$ & $\begin{array}{l}\text { Increased } \\
\text { Importance } \\
\text { Profitability }\end{array}$ & $\begin{array}{l}\text { Increased } \\
\text { Importance }\end{array}$ \\
Strategic Fit & & $\begin{array}{l}\text { Increased } \\
\text { Decreased } \\
\text { Importance } \\
\text { Importance }\end{array}$ & Impotitiveness \\
Increased & & Increased \\
Communications & & Importance & Increased \\
Implementability & & Importance & Decreased Importance \\
\hline
\end{tabular}

Notes 